\title{
Immunohistochemical Study Of Bcl-2 Protein And Estrogen Receptor-Alpha Expression In Benign Prostatic Hyperplasia And Prostatic Carcinoma
}

\author{
Ahmed H. Abel-Rahman- Ghada A. Abdel-Aziz*- Ali Emad S**- Abdel- \\ Basset A. Badawy***- Alaa Ar. Abdel-Hafez*** \\ Departments of Pathology, Dermatology \& Veneriology* and Urology** \\ Al-Azhar University (Assiut \& Girls) and South Valley University***
}

\begin{abstract}
:
The human prostate, a male sexual accessory tissue involved in seminal fluid production, has a remarkably high incidence of hyperplastic and neoplastic disease. The present study was carried out on one hundred and twenty (120) specimens divided into two groups; group 1: Included forty cases of benign prostatic hyperplasia (BPH) and group 2: Included sixty cases of prostatic adenocarcinoma (PC) (22 were low grade; GS: 2-6 and 38 were high grade; GS: 710), in addition to twenty cases of histologically normal prostates taken as controls. Immunohistochemical technique was applied to detect $\mathrm{Bcl}-2$ as well as ER $\alpha$ positivity in all specimens. Group 1 showed the following profile: ER $\alpha(+)$ in all cases $(100 \%)$, Bcl-2 (-) in 95\%, $\mathrm{ER} \alpha(+) / \mathrm{Bcl}-2(+)$ in 95\%, $\mathrm{ER} \alpha(-) / \mathrm{Bcl}-2(+)$ in 0\%, $\mathrm{ER} \alpha(+) / \mathrm{Bcl}-2(-)$ in $5 \%$ and $\mathrm{ER} \alpha$ $(-) / \mathrm{Bcl}-2(-)$ in $0 \%$ of cases while group 2 showed the following profile: $\mathrm{ER} \alpha(+)$ in $30 \%$, Bcl-2 $(+)$ in $21.7 \%, \mathrm{ER} \alpha(+) / \mathrm{Bcl}-2(+)$ in $15 \%, \mathrm{ER} \alpha(-) / \mathrm{Bcl}-2(+)$ in $6.7 \%, \mathrm{ER} \alpha(+) / \mathrm{Bcl}-2(-)$ in $15 \%$ and ER $\alpha(-) / \mathrm{Bcl}-2(-)$ in $70 \%$ of cases. The mean epithelial ER $\alpha$-immunolabeling was, however, significantly increased in group 2 than in group $1(\mathrm{P}<0.05)$ which, in turn, being higher than the normal cases $(\mathrm{P}<0.05)$. Among group 2 , the mean ER $\alpha \square$ immunolabeling was significantly more in high grade than in low grade tumors $(\mathrm{P}<0.05)$, however, the mean ER $\alpha$ immunolabeling revealed no significant correlation with $\mathrm{T}$-stage $(\mathrm{P}=0.219)$ or with the clinical stage $(\mathrm{P}=0.391)$. In contrast, the $\mathrm{Bcl}-2$ immunostaining was statistically higher in group 1 than in group $2(\mathrm{P}<0.05)$ and showed a significant correlation with $\mathrm{T}$ stage $(\mathrm{P}<0.05)$ although the study displayed no significant correlation between Bcl-2 immunopositivity and either Gleason score $(\mathrm{P}=0.125)$ or the histologic grade $(\mathrm{P}=0.146)$. In addition, combined ER $\alpha$ $(+) / \mathrm{Bcl} 2(+)$ immunoreactivity demonstrated the aggressive subgroup of PC cases more accurately than either ER $\alpha(+)$ or Bcl-2 (+) alone. Finally, multivariate analysis showed that the $\mathrm{Bcl}-2$, proved to be an independent prognostic indicator $(\mathrm{P}<0.05)$. Thus, the immunohistochemical expression of ER $\alpha$ and $\mathrm{Bcl}-2$ protein in prostatic tissue may aid in better understanding the biology and genesis of both prostatic hyperplasia and carcinoma .
\end{abstract}

Key words: Bcl-2, Estrogen receptor-alpha, Immunohistochemistry, Benign prostatic hyperplasia, Prostatic carcinoma.

\section{Introduction:}

Benign prostatic hyperplasia $(\mathrm{BPH})$ occurs in approximately $70 \%$ of men over 70 years old and develops at a time when the levels of testosterone are falling and estrogen levels are rising, thus, resulting in an increase in the estrogen: androgen ratio $^{(1)}$. This age-related shift in the hormonal balance has been suspected to be implicated in the etiology of $\mathrm{BPH}$ particularly following the discovery that 17 $\beta$-estradiol acts synergistically with testosterone in experimentally induced $\mathrm{BPH}$ in the $\operatorname{dog}^{(2)}$. For estrogen to be directly involved in the genesis of human $\mathrm{BPH}$, the prostate 
must contain estrogen receptors (ERs) which should be up-regulated as in the canine model ${ }^{(3)}$.

In addition, estrogen therapy or orchidectomy has been the standard treatment for advanced prostate cancer in the last decades ${ }^{(4)}$. However, the exact mechanism of estrogen action in the prostate is not yet completely understood. This might be partially attributed to the lack of functional studies, together with controversial immunocytochemical data regarding the localization of ERs ${ }^{(5)}$.

Estrogen receptors are members of a nuclear receptor superfamily of ligandactivated transcription factors ${ }^{(6)}$. Two different ERs (ER- $\alpha$ and ER- $\beta$ ) have been described and shown to be critically and differently involved in the regulation of the normal function of the reproductive tissue $^{(7)}$. In human, ER $\beta$ has a molecular mass of $66 \mathrm{KDa}$ and has been demonstrated in the prostate ${ }^{(8)}$ while ER- $\alpha$ has a molecular mass of $54.2 \mathrm{KDa}$ and has been obtained from the testis ${ }^{(9)}$. Structurally, ER$\beta$ is highly homologous to ER- $\alpha$ in the DNA binding domain $(95 \%$ amino acid identity) but shows only $60 \%$ homology (compared to $88 \%$ for ER- $\alpha$ ) in the ligand binding domain ${ }^{(10)}$. Despite the demonstration of ER- $\alpha$ in human prostate, the results from different studies are contradictory. Several investigators have confined this receptor to the stromal compartment of the prostate ${ }^{(11,12)}$ whereas others have localized it in the epithelial compartment ${ }^{(13)}$. Also, there is no overall agreement on the association between ER- $\square \alpha$ and prostatic neoplasia since this receptor has been demonstrated in several prostate cancer cell lines ${ }^{(14-16)}$ but not in others ${ }^{(6,17,18)}$.

Bcl-2, an apoptosis-suppressing oncogene, was initially identified via the study of $\mathrm{t}(14 ; 18)$ translocation and frequently found in B-cell leukaemia and non Hodgkin lymphoma ${ }^{(19)}$. Its expression is restricted to generative (and potentially stem cell) populations in normal tissues ${ }^{(20)}$. In addition, this protein has been shown to provide protection from apoptotic stimuli when it is overexpressed $^{(21)}$.Normal prostatic epithelium is dependent upon androgens for its integrity and proliferation ${ }^{(22)}$. Moreover, many prostatic carcinomas are initially androgen-dependent but finally become androgen-independent. The genetic alterations behind- that transition have not yet elucidated, however, Bcl-2 may play an important role in the emergence of androgen-independent prostatic cancer ${ }^{(23)}$.

Since the normal and neoplastic prostatic epithelia, following androgen deprivation had undergone programmed cell death, however, the hyperplastic gland did not demonstrate apoptosis but rather upregulated expression of anti apoptotic Bcl-2 protein ${ }^{(24)}$.

Based on the importance of apoptosis to prostate cancer therapies and the inherent resistance to apoptosis in the subpopulations of metastatic prostate cancer cells, this protein presents a logical target for a role in human prostate cancer ${ }^{(25)}$. Thus, the purpose of this study is to investigate the expression and role of Bcl-2 protein as well as ER- $\alpha$ in the development of both benign prostatic hyperplasia (BPH) and prostatic

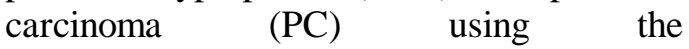
immunohistochemistry.

\section{Materials and methods}

This study consisted of a sum of one hundred and twenty (120) prostatic biopsy specimens divided into two groups; group 1: Included forty (40) cases of BPH treated by transrectal sonar guided resection. The patients (range 53-88 years; mean 64.8 years) did not recieve hormonal therapy before the surgery and group 2: Included sixty (60) cases of PC. The patients' ages in this group ranged from 48 to 87 years (mean 71 years). TNM classification divided this group into the following stages: 13 cases were in $\mathrm{T}_{1} \mathrm{~N}_{0} \mathrm{M}_{0}, 20$ in $\mathrm{T}_{2} \mathrm{~N}_{0} \mathrm{M}_{0}$, 16 in $\mathrm{T}_{3} \mathrm{~N}_{0} \mathrm{M}_{0}, 6$ in Tany $\mathrm{N}_{1} \mathrm{M}_{0}$ and 5 in Tany Nany $\mathrm{M}_{1}$ (Table 1 ).

The group 2 patients underwent transrectal ultrasound guided biopsy and seven, received androgen ablative treatment in form of Luteinizing hormone-releasing hormone (LH-RH) agonist combined with flutamide or chlormadinone acetate. Anticancer chemotherapy had not been performed until the disease progression 
after androgen ablation. Radiotherapy was carried out only for palliative purposes. The mean follow-up period was 35.5 months (range, 1 to 66 months). Eighteen patients (30\%) died of prostatic cancer and four $(6.7 \%)$ died of other causes. The average survival time was 29.8 months (range, 1 to 60 months). In addition, twenty (20) histologically normal prostatic tissue biopsies, taken from radical cystectomy specimens, were used as controls.

All specimens were obtained from Pathology Department, Al-Azhar University Hospitals during the period between January 1, 1998 and June 30, 2003. The clinicopathological variables as well as the results of follow-up were taken from the patients' files.

\section{Histopathological and immunohistoche- mical procedures:}

Needle core prostatic biopsy specimens prior to initiation of any treatment for prostatic cancer were submitted for the study.

Formalin-fixed, paraffin-embedded blocks were sectioned at $5 \mu$ thickness. One section was stained with hematoxylin and eosin for thorough histopathological examination to confirm the diagnosis. All group 2 cases were diagnosed as adenocarcinoma. Gleason score (GS) was determined by adding the numbers for the two most predominant patterns. Accordingly twenty-two (22/60-36.7\%) of prostatic adenocarcinoma were low grade $(\mathrm{GS}=2-6)$ while the remainings (38/60-63.3\%) were high grade $(\mathrm{GS}=7-10)$. Additional sections were used for immunohistochemical study to investigate the expression of ER- $\alpha$ and Bcl-2 immunoreactivity as follows. Sections, on poly-L-lysine coated glass slides, were deparaffinized in xylene and rehydrated using ethanol gradients. The sections were pretreated three times in a microwave oven for 5 minutes in citrate solution (Biogenex-Neufahrn, Germany). Endogenous peroxidase activity was blocked by emmersion in methanol with $0.3 \%$ hydrogen peroxidase for 30 minutes. Non-specific binding was blocked by incubation with horse non-immune serum for 20 minutes. The slides were incubated overnight at $4^{\circ} \mathrm{C}$ with mouse monoclonal primary antibodies for ER- $\alpha$ (Clone ID5N1575, Dako) and for Bcl-2 oncoprotein (Clone 124, Dako, Glostrup, Denmark). The slides were incubated with biotinylated rabbit anti-mouse secondary immunoglobulins (Vector Laboratories, Inc., Burlingame, CA) for 30 minutes at room temperature. They were subsequently incubated with avidin-biotin peroxidase complex (Vectastain Elite Kit, Vector Laboratories, Burlingame Inc.). 3,3 diaminobenzidine (Dako, Corp., Carpinteria, CA) was used as a chromogen. The sections were counterstain with hematoxylin.

Positive reaction for ER- $\alpha$ appeared as a brown nuclear staining in the epithelial and stromal cells. For a histological comparative quantification of ER- $\alpha$ immuneolabeling in both groups, a great number of sections (23 in BPH and 29 in PC) were taken from the impaired zone. Moreover, from each normal prostate specimen, 6 histological sections of each region (central, intermediate and peripheral) were selected at random. In each section, the percentage of immunolabeled nuclei (in a total of 1000 nuclei examined for region) was calculated using the $\mathrm{x} 40$ objective. Of the average values obtained for each prostatic specimen, the mean \pm S.D. for each group and for the normal cases was calculated. In this study, the number of sections was the minimum number required to reach the lowest S.D.

Positive Bcl-2 reaction appeared as a brown cytoplasmic staining in the epithelial cells. The proportion and the intensity of Bcl-2 immunostaining were evaluated. The scoring for intensity, based on the relative intensity of brown epithelial cell staining area compared to consistently negative stromal cell staining one, was graded into: trace: $\leq 5 \%, 1(+): 6-25 \%, 2(+): 26-50 \%$ and $3(+)>50 \%$.

\section{Statistical analysis:}

The statistical significance between means and the comparison of proportions was assessed using ANOVA and Fisher exact probability test and also the chisquare test. The significance between the studied groups was evaluated by the Logrank test 
and the Cox proportional hazard test. The hazard ratio corresponding to each factor in the study was determined. A hazard ratio of 1 indicates equivalent survival for the different levels of a study factor. A probability levels of $\leq 0.05$ or $\leq 0.001$ were used to indicate a statistical significance.

\section{Results}

Histologic examination of the prostatic tissue revealed the presence of three kinds of epithelial cells; normal glands composed of a single layer of cuboidal and an underlying basal epithelial layer, hyperplastic glands with columnar epithelium that is often multilayered (Fig. 1) and malignant epithelium of varying histologic architecture (Fig. 2).

\section{ER- $\alpha$ immunohistochemistry:}

Immunostaining for ER- $\alpha$ showed differences among the two groups (Table 2). Cell immunolabeling was usually observed in the nuclei and only occasionally in the cytoplasm. ER- $\alpha$ immunolabeled nuclei were demonstrated in all cases of group 1 (Fig. 3) as well as in all control cases, however, they were only found in eighteen $(18 / 60=30 \%)$ of group 2 cases (Fig. 4). Among the group 2 cases, 6 out of $22(27.3 \%)$ were low grade (GS: 2-6) while the remainings $(12 / 38-31.6 \%)$ were high grade (GS: 7-10) tumors. Also, four ER- $\alpha(+)$ cases were in $T_{1}$, six were in $T_{2}$ and eight were in $\mathrm{T}_{3}$ stage. Moreover, ten cases were localized $\left(\mathrm{N}_{0} \mathrm{M}_{0}\right)$ and 8 were metastatic $\left(\mathrm{N}_{1}\right.$ or $\left.\mathrm{M}_{1}\right)$. A significant difference was noticed between low grade and high grade ER- $\alpha \quad(+)$ tumors $(\mathrm{P}=$ 0.041 ) while no significant correlation between ER- $\alpha$ immunopositivity and either $\mathrm{T}$ stage $(\mathrm{P}=0.219)$ or the clinical stage $(P=0.391)$. The mean epithelial immunostaining for ER- $\alpha$ in group 2 cases was higher than in group 1 cases (about $70 \%$ of group 2 epithelial cell nuclei compared to only about $10 \%$ of group 1 nuclei were ER- $\alpha$ immunostained). In normal cases, the epithelial immunostaining for ER- $\alpha$ was limited to scattered nuclei $(0.6 \%)$ in the basal layer. On the contrary, about $15 \%$ of the stromal cell nuclei in both groups as well as in the normal cases were positively immunostained

\section{Bcl-2 immunohistochemistry:}

Bcl-2 immunostaining showed a significant difference $(\mathrm{P}=0.031)$ between the two groups (Table 3). In group 1, positive bcl-2 cytoplasmic staining was found,throughout the hyperplastic epithelial cells particularly in the basal layer, in 38 out of 40 cases (95\%, Fig. 5). The intensity of staining was intense $(3+)$ in 8 , moderate $(2+)$ in 15 , weak (+) in 10 and trace in 5 cases. On the other hand, Bcl-2 immunostaining in group 2 was displayed in infiltrating lymphocytes as well as in malignant cells but only the positive malignant cells were considered in this study. Bcl-2 immunopositivity was detected in 13 (Fig. 6) out of the 60 group 2 cases $(13 / 60-21.7 \%)$. Within the group 2 , seven of the positive cases (7/38-18.4\%) were high grade (GS: 7-10) and the remainings (6/22-27.3\%) were lower grade (GS: 6; but none was of GS $\leq 5$ ). The staining intensity was trace $(\leq 5 \%)$ in three $(3 / 13-23 \%)$ cases (all were of GS6) and weak (1+) in ten (10/13-77\%) cases (seven were of GS 7-10 and three were of GS6). Also, Bcl-2 positive immunoreactivity was demonstrated in $22.4 \%$ (11 out of 49 ) of localized $\left(\mathrm{N}_{0} \mathrm{M}_{0}\right)$ and in $18.2 \%$ (2 out of 11) of metastatic $\left(\mathrm{N}_{1}\right.$ or $\left.\mathrm{M}_{1}\right)$ tumors. Moreover, two of the Bcl-2 (+) localized cancer cases were $\mathrm{T} 1$ (2/13-15.4\%), two were $\mathrm{T}_{2}(2 / 20$ $10 \%)$ and seven were $\mathrm{T}_{3}(7 / 16-43.8 \%)$. The Bcl-2 positivity in $\mathrm{T}_{3}$ tumors was significantly higher than in $\mathrm{T}_{1+2}(\mathrm{P}=0.017)$, however, no significant difference in Bcl-2 immunostaining between high grade (GS: 7-10) and lower grade (GS: 6) tumors ( $\mathrm{P}=$ $0.146)$ or between localized and metastatic cancer cases $(\mathrm{P}=0.344)$. In normal cases, Bcl-2 (+) immunoreactivity was noticed in ten $(10 / 20-50 \%)$ cases uniformly in the basal epithelium while the secretory, or luminal, cell component of the normal glandular epithelium was virtually Bcl-2 negative. The staining intensity was moderate $(2+)$ in 2 , weak (1+) in 5 and trace in 3 cases. 
Relationship between ER- $\alpha$ and Bcl-2 expression (Table 4):

In group 1, combined ER- $\alpha$ and Bcl2 immunostaining showed the following profile: ER- $\alpha(+) / \mathrm{Bcl}-2(+)$ in $95 \%$ of cases (38/40), ER- $\alpha$ (+)/ Bcl-2 (-) in 5\% (2/40), ER- $\alpha$ (-) $/ \mathrm{Bcl}-2(+)$ in $0 \%$ and ER- $\alpha(-) /$ $\mathrm{Bcl}-2$ (-) in $0 \%$. In group 2, combined immunostaining also classified the cases into four phenotypes: ER- $\alpha$ (+) / Bcl-2 (+) in 9 cases $(5 \%)$ including 6 high grade (GS: 7-10) and 3 lower grade (GS: 6), ER- $\alpha$ (+) / Bcl-2 (-) in 9 (15\%), ER- $\alpha$ (-) / Bcl-2 (+) in $4(6.7 \%)$ and ER- $\alpha$ (-) / Bcl-2 (-) in 42 (70\%). In group 2, the ER- $\alpha$ (-) / Bcl-2 (-) phenotype showed a significantly better prognosis than either ER- $\alpha(+)$ or $\mathrm{Bcl}-2(+)$ phenotype $(\mathrm{P}<0.001$ by Logrank test $)$. Pearson correlation analysis revealed that ER- $\alpha$ and Bcl-2 were independently expressed $(\mathrm{P}=0.980)$. Moreover,combined immunostaining for ER- $\alpha$ and Bcl-2 differentiated the patients with poorer prognosis more accurately than ER- $\alpha$ or Bcl-2 staining alone, since both molecules were fairly independently expressed in prostatic carcinomas.

Multivariate analysis in group 2 using Cox proportional hazard model revealed that the Bcl-2, Gleason score and clinical stage were significant prognostic factors on overall survivals (Table 5).

Table (1): Histopathological diagnosis in all studied cases

\begin{tabular}{|c|c|c|}
\hline Diagnosis & No; & Percentage $(\%)$ \\
\hline Group 1: Benign prostatic hyperplasia (BPH) & 40 & 33.3 \\
\hline Group 2: Prostatic adenocarcinoma (PC): & 60 & 50.0 \\
\hline TNM classification: & & \\
\hline $\mathrm{T}_{1}$ No $\mathrm{M}_{0}$ & 13 & 21.7 \\
\hline $\mathrm{T}_{2} \mathrm{No} \mathrm{M}_{0}$ & 20 & 33.3 \\
\hline $\mathrm{T}_{3} \mathrm{No} \mathrm{M}_{0}$ & 16 & 26.7 \\
\hline Tany $\mathrm{N}_{1} \mathrm{M}_{0}$ & 6 & 10.0 \\
\hline Tany Nany $\mathrm{M}_{1}$ & 5 & 8.3 \\
\hline Clinical stage : & & \\
\hline Localized $\left(\mathrm{N}_{0} \mathrm{M}_{0}\right)$ & 49 & 81.7 \\
\hline Metastatic $\left(\mathrm{N}_{1}\right.$ or $\left.\mathrm{M}_{1}\right)$ & 11 & 18.3 \\
\hline Histologic grade : & & \\
\hline Low grade $*($ GS: $2-6)$ & 22 & 36.7 \\
\hline High grade $*(G S: 7-10)$ & 38 & 63.3 \\
\hline Normal (control ) & 20 & 16.7 \\
\hline Total & 120 & 100 \\
\hline
\end{tabular}

* GS = Gleason score 
Table (2): ER- $\alpha$ immunolabeled nuclei in all studied cases $(\mathbf{N}=120)$

\begin{tabular}{|l|l|l|l|}
\hline \multirow{2}{*}{ Group } & \multicolumn{2}{|l|}{$\begin{array}{l}\text { ER- } \alpha \\
\text { Positive cases }\end{array}$} & $\begin{array}{l}\text { ER- } \alpha \text { immunolabeled nuclei } \\
(\%)^{\bullet}\end{array}$ \\
\cline { 2 - 4 } & No & $\%$ & Mean** \pm SD \\
\hline Group 1: BPH $(\mathrm{n}=40)$ & 40 & 100 & $14.6 \pm 2.1 \mathrm{a}^{*}$ \\
Stroma & & & $10.4 \pm 1.9 \mathrm{~b}^{*}$ \\
Epithelium & 18 & 30 & $15.8 \pm 4.8 \mathrm{a}^{*}$ \\
\hline Group 2: PC $(\mathrm{n}=60)$ & & & $69.9 \pm 6.2 \mathrm{c}^{*}$ \\
Stroma & & & \\
$\bullet \bullet$ Epithelium: & 6 & 27.3 & $29.5 \pm 3.2 \mathrm{~d}^{*}$ \\
$\bullet \bullet$ Histologic grade: & 12 & 31.6 & $76.2 \pm 8.7 \mathrm{c}^{*}$ \\
Low grade $(\mathrm{GS}=2-6 ; \mathrm{n}=22)$ & 8 & 24.2 & $72.7 \pm 6.4 \mathrm{c}^{*}$ \\
High grade $(\mathrm{GS}=7-10 ; \mathrm{n}=38)$ & 4 & 27.5 & $69.2 \pm 5.9 \mathrm{c}^{*}$ \\
$\bullet \bullet$ TNM stage: & & & \\
$\mathrm{T}_{1+2}+\mathrm{N}_{0} \mathrm{M}_{0}(\mathrm{n}=33)$ & 12 & 24.5 & $76.7 \pm 6.9 \mathrm{c}^{*}$ \\
$\mathrm{~T}_{3} \mathrm{~N}_{0} \mathrm{M}_{0}(\mathrm{n}=16)$ & 6 & 54.5 & $73.1 \pm 7.5 \mathrm{c}^{*}$ \\
$\bullet \bullet$ Clinical stage: & 20 & 100 & \\
Localized $\left(\mathrm{N}_{0} \mathrm{M}_{0} ; \mathrm{n}=49\right)$ & & & $15.1 \pm 1.8 \mathrm{a}^{*}$ \\
Metastatic $\left(\mathrm{N}_{1}\right.$ or $\left.\mathrm{M}_{1} ; \mathrm{n}=11\right)$ & & & $0.6 \pm 0.2 \mathrm{e}^{*}$ \\
\hline Normal $(\operatorname{control}):(\mathrm{n}=20)$ & & & \\
Stroma & &
\end{tabular}

- ER- $\alpha$ immunolabeled nuclei were calculated as a percentage.

** The mean values and standard deviation (S.D.) for each group have been calculated from all specimens corresponding to the group.

- Comparison of subgroups 2 occurs regarding the ER- a immunolabeled nuclei in the malignant epithelium

* Values with a different superscript letter differ significantly $(P<0.05)$.

Table (3): Bcl-2 positivity in all studied cases $(\mathrm{N}=120)$

\begin{tabular}{|c|c|c|c|c|c|c|c|}
\hline \multirow[b]{2}{*}{ Group } & \multicolumn{6}{|c|}{ Bcl-2 positivity } & \multirow[b]{2}{*}{$\mathrm{P}$ value } \\
\hline & No & $\%$ & $\begin{array}{c}\text { Intense } \\
(3+)\end{array}$ & $\begin{array}{c}\text { Mod. } \\
(2+)\end{array}$ & $\begin{array}{c}\text { Weak } \\
(1+)\end{array}$ & Trace () & \\
\hline Group 1: $\mathrm{BPH}(\mathrm{n}=40)$ & 38 & 95 & 8 & 15 & 10 & 5 & \\
\hline Group 2: $\mathrm{PC}(\mathrm{n}=60)$ & 13 & 21.7 & 0 & 0 & 10 & 3 & 0.031 \\
\hline $\begin{array}{l}\text { Gleason score }(\mathrm{GS}): \\
2-5(\mathrm{n}=8) \\
6(\mathrm{n}=14) \\
7-10(\mathrm{n}=38)\end{array}$ & $\begin{array}{l}0 \\
6 \\
7\end{array}$ & $\begin{array}{c}0 \\
42.8 \\
18.4\end{array}$ & $\begin{array}{l}0 \\
0 \\
0\end{array}$ & $\begin{array}{l}0 \\
0 \\
0\end{array}$ & $\begin{array}{l}0 \\
3 \\
7\end{array}$ & $\begin{array}{l}0 \\
3 \\
0\end{array}$ & $0.125^{*}$ \\
\hline \begin{tabular}{lc}
\multicolumn{2}{c}{ Histologic grade : } \\
Low grade & (GS: 2-6) \\
High grade & (GS: 7-10)
\end{tabular} & $\begin{array}{l}6 \\
7\end{array}$ & $\begin{array}{l}27.3 \\
18.4\end{array}$ & $\begin{array}{l}0 \\
0\end{array}$ & $\begin{array}{l}0 \\
0\end{array}$ & $\begin{array}{l}3 \\
7\end{array}$ & $\begin{array}{l}3 \\
0\end{array}$ & $0.146^{*}$ \\
\hline $\begin{array}{l}\text { TNM stage : } \\
\mathrm{T}_{1+2} \mathrm{~N}_{0} \mathrm{M}_{0} \quad(\mathrm{n}=33) \\
\mathrm{T}_{3} \mathrm{~N}_{0} \mathrm{M}_{0} \quad(\mathrm{n}=16) \\
\text { Tany } \mathrm{N}_{1} \mathrm{M}_{0}+\text { Tany Nany } \mathrm{M}_{1}(\mathrm{n}=11)\end{array}$ & $\begin{array}{l}4 \\
7 \\
2\end{array}$ & $\begin{array}{l}12.1 \\
43.8 \\
18.2\end{array}$ & $\begin{array}{l}0 \\
0 \\
0\end{array}$ & $\begin{array}{l}0 \\
0 \\
0\end{array}$ & $\begin{array}{l}1 \\
7 \\
2\end{array}$ & $\begin{array}{l}3 \\
0 \\
0\end{array}$ & $0.017^{\bullet}$ \\
\hline \begin{tabular}{lc}
\multicolumn{2}{c}{ Clinical stage : } \\
Localized $\quad\left(\mathrm{N}_{0} \mathrm{M}_{0}\right)$ \\
Metastatic & $\left(\mathrm{N}_{1}\right.$ or $\left.\mathrm{M}_{1}\right)$ \\
Normal $($ control $)(\mathrm{n}=20)$
\end{tabular} & $\begin{array}{c}11 \\
2 \\
10\end{array}$ & $\begin{array}{c}22.4 \\
18.2 \\
50\end{array}$ & $\begin{array}{l}0 \\
0 \\
0\end{array}$ & $\begin{array}{l}0 \\
0 \\
2\end{array}$ & $\begin{array}{l}8 \\
2 \\
5\end{array}$ & $\begin{array}{l}3 \\
0 \\
3\end{array}$ & $0.344^{*}$ \\
\hline
\end{tabular}

$B P H=$ Benign prostatic hyperplasia, $P C=$ Prostatic adenocarcinoma, Mod $=$ Moderate

$T=$ Tumor size (cm); $N=$ Lymph nodal metastasis; $M=$ Distant metastasis

- Significant $P$ value *Insignificant $P$-value 
Table (4): Relationship between ER- $\alpha$ and Bcl-2 expression in both groups $(\mathbf{n}=100)$

\begin{tabular}{|c|c|c|c|c|}
\hline \multirow[t]{2}{*}{ Phenotype } & \multicolumn{2}{|c|}{ Group $1 *$ BPH $(n=40)$} & \multicolumn{2}{|c|}{ Group $2^{\bullet} \mathrm{PC}(\mathrm{n}=60)$} \\
\hline & No & $* * \%$ & No & $* * \%$ \\
\hline $\mathrm{ER} \alpha(+) / \mathrm{Bcl}-2(+)$ & 38 & 95 & 9 & 15 \\
\hline $\operatorname{ER} \alpha(+) / \operatorname{Bcl}-2(-)$ & 2 & 5 & 9 & 15 \\
\hline $\mathrm{ER} \alpha(-) / \mathrm{Bcl}-2(+)$ & 0 & 0 & 4 & 6.7 \\
\hline $\mathrm{ER} \alpha(-) / \mathrm{Bcl}-2(-)$ & 0 & 0 & 42 & 70 \\
\hline
\end{tabular}

$* B P H=$ Benign prostatic hyperplasia;

- $P C=$ Prostatic adenocarcinoma

** $\%=$ Percentage of the number of each phenotype divided by the total number of corresponding group cases.

Table (5): Prognostic indicators in group 2 cases by Cox multivariate analysis( $(n=60)$

\begin{tabular}{|l|c|c|c|}
\hline Prognostic indicators & Beta & Hazard ratio & P-value \\
\hline Bcl-2 immunostaining: & 0.000 & 1.000 & \\
Negative & 0.854 & 2.931 & $0.001^{\bullet}$ \\
Positive & & & \\
& & & \\
ER- $\alpha$ immunostaining: & 0.000 & 1.000 & \\
Negative & 0.521 & 1.613 & $0.242^{*}$ \\
Positive & 0.000 & 1.000 & \\
Gleason score (GS): & 0.328 & 1.362 & $0.023^{\bullet}$ \\
2-6 & & & \\
7-10 & 0.000 & 1.000 & $0.002^{\bullet}$ \\
Clinical stage: & 1.245 & 4.237 & \\
Localized $\left(\mathrm{N}_{0} \mathrm{M}_{0}\right)$ & & & \\
\hline
\end{tabular}

- Significant $P$-value *Insignificant $P$-value

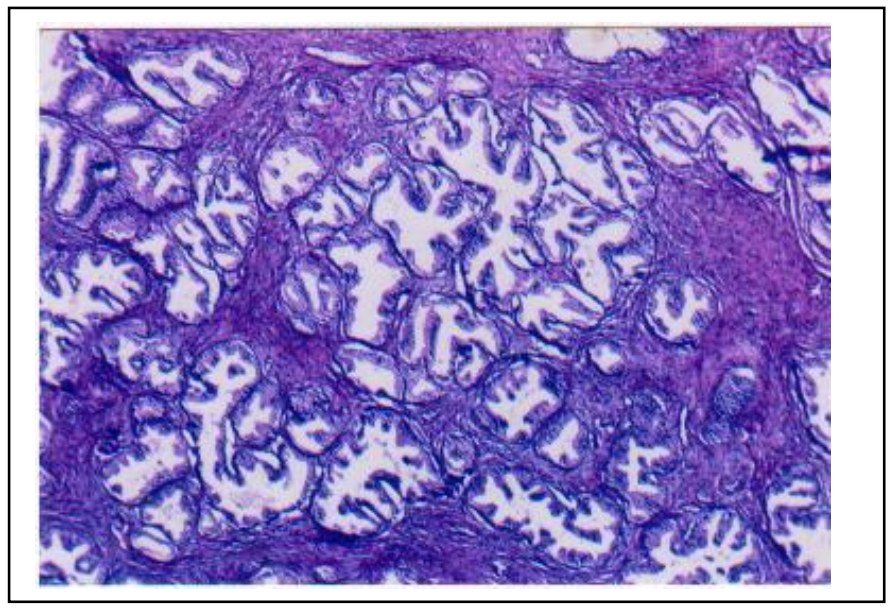

Fig. (1): A case of benign prostatic hyperplasia (BPH) showing proliferating glands lined with multilayered epithelium thrown into intraluminal papillae.

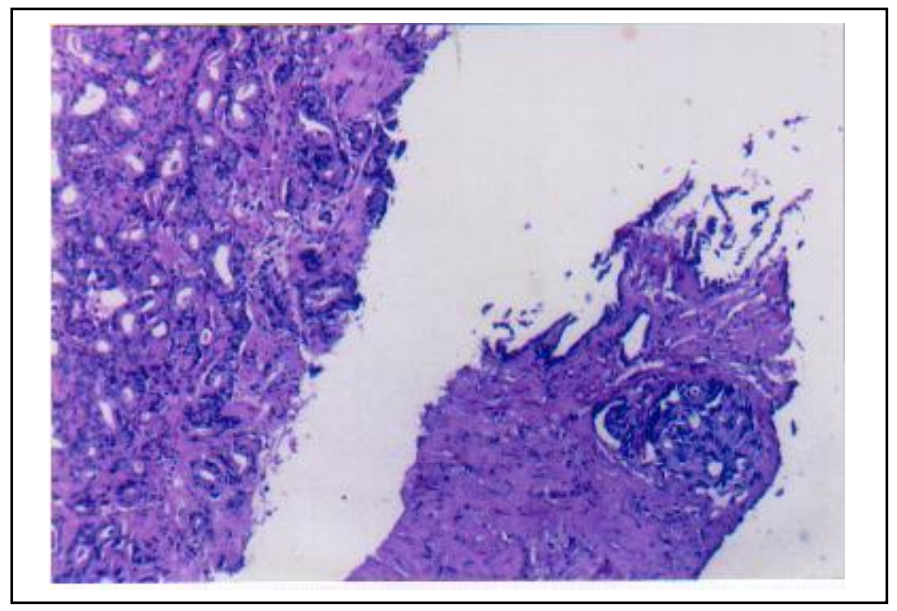

Fig. (2): A case of prostatic adenocarcinoma (PC), Gleason score 5 " $2+3$ " .

(Hx\& E . X100)

(Hx \& E . X40) 


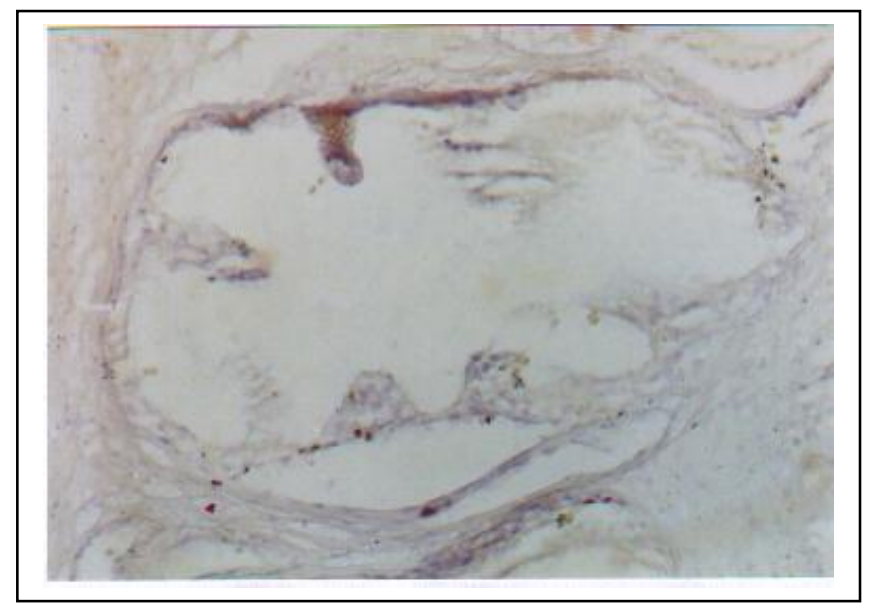

Fig. (3): A case of BPH showing a positive nuclear ER- $\alpha$ immunoreactivity (brownish coloration) in the hyperplastic epithelium

(Immunoperoxidase [IP] X 200).

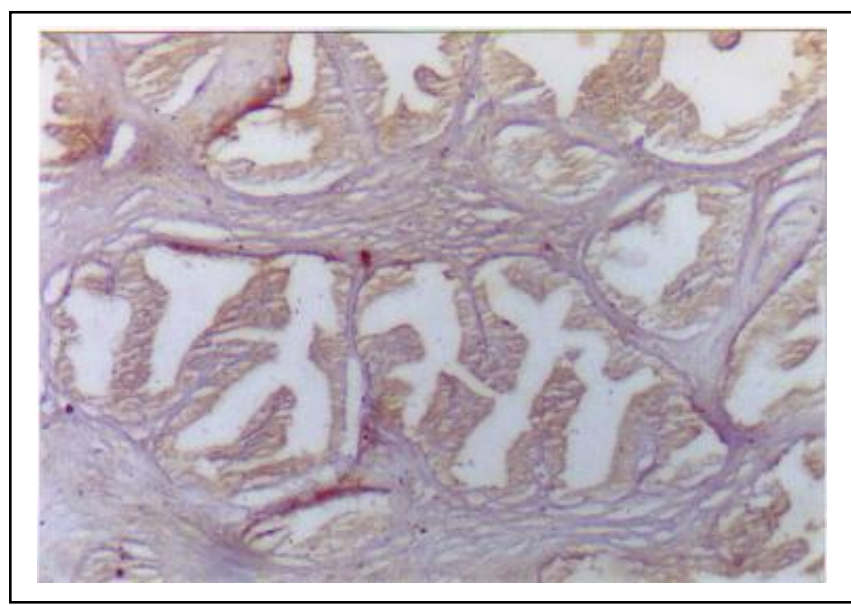

Fig. (5): A case of BPH showing a positive cytoplasmic Bcl-2 immunoreactivity (brownish coloration) in the hyperplastic epithelium .

(IP X100).

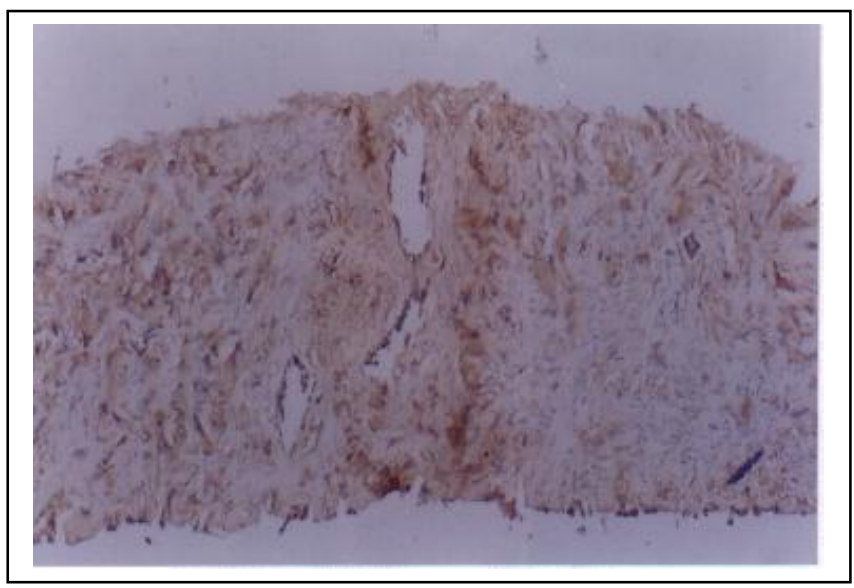

Fig. (4): A case of PC, Gleason score 3 "1+2" showing a malignant gland lined with positive (nuclear) ER$\alpha$ immunoreactive cells.

(IP X100).

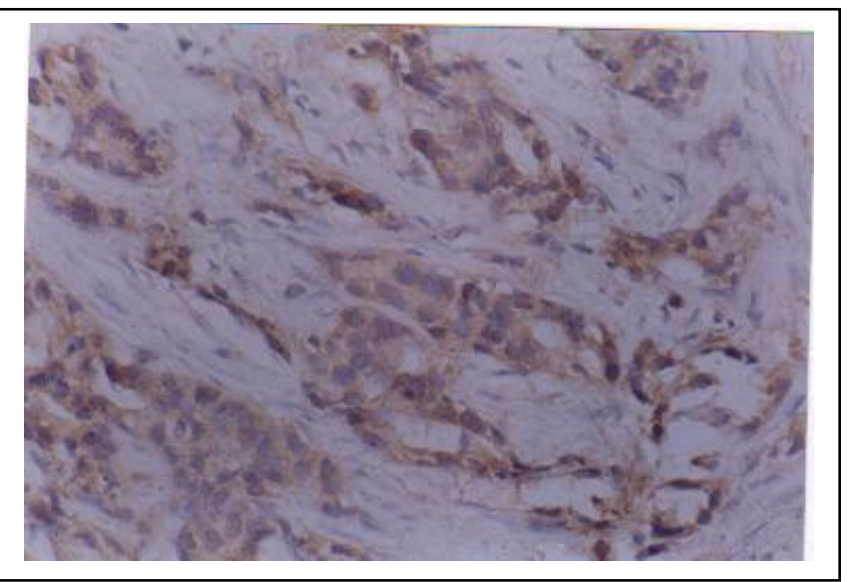

Fig. (6): A case of PC, Gleason score 7 " $3+4$ " showing a positive cytoplasmic Bcl-2 immunoreactive malignant epithelium.

(IP X400).

\section{Discussion:}

Benign prostatic hyperplasia is a physiologic condition involving exuberant growth of the central zone of the human prostate that begins sometimes during the midlife. Estrogens are implicated in the prostatic growth and the hyperplastic changes seen in the prostate have been related to exposure of the prostatic tissue to increased intraprostatic and circulating

estrogen levels (26). Moreover, the hyperplastic epithelial cells themselves are androgen-dependent and become resistant to apoptosis induced by androgen withdrowal $^{(24)}$.

In the present study, ER- $\alpha$ was immunodetected in the nuclei of the stromal as well as of the epithelial cells. In addition, the cytoplasmic immunolabeling was only 
occasionally observed. The data coincided with those mentioned by Ehara et al., ${ }^{(12)}$ and Brolin et al. ${ }^{(17)}$ who attributed the cytoplasmic immunolabeling to the probability of presence of hormone binding transport protein.

Our study revealed that the mean epithelial ER- $\alpha$ immunostaining was significantly greater in group 2 than in group $1(\mathrm{P}<0.05)$ although the positivity was only in $30 \%$ of group 2 cases compared to group 1 cases $(100 \%)$. Moreover, the study demonstrated that the epithelial immunostaining for ER- $\alpha$ was higher in group 1 than in normal cases $(\mathrm{P}<0.05)$ and showed these receptors in all normal cases. In contrast, the mean stromal ER- $\alpha$ immunolabeling was near (about 15\%) in the normal, hyperplastic and neoplastic prostatic tissue $(\mathrm{P}=0.431)$. These findings were mimicing those reported by Mobbs et $a l .,{ }^{(27)}$ and Pennie et al., ${ }^{(28)}$ who resorted the presence of ERs in both epithelium and stroma to the involvement of estrogens in the growth, differentiation and maintenance of the prostate. On the contrary, our results were discrepant to those mentioned by Konishi et al. ${ }^{(18)}$ who found that ERs were less abundant in $\mathrm{PC}$ than in $\mathrm{BPH}$ specimens.

This study also showed that the percentage of malignant epithelial ER- $\alpha$ immunolabeling was significantly higher in high grade (G5:7-10) than in low grade (GS: 2-6) tumors $(\mathrm{P}<0.05)$, however, no significant difference was noticed between $\mathrm{T}_{1+2}$ and $\mathrm{T}_{3}$ localized $\mathrm{PC}(\mathrm{P}=0.219)$ or between the localized and metastatic tumors $(\mathrm{P}=0.391)$. The findings were similar to those reported by Srinivasan et al., ${ }^{(16)}$ and Bonkhoff et $a l .,{ }^{(29)}$ who positively correlated the abundance of ERs with the histologic grade of prostatic carcinomas and suggested that estrogens favor cancer development in prostate by stimulation of the cell proliferation. On the other hand, the results were opposite those found by Kirschenbaum et al., ${ }^{(30)}$ who established a negative correlation between the presence of these receptors and malignancy.

We found, as well statistically higher Bcl-2 expression in group 1 than in group 2 cases $(\mathrm{P}<0.05)$. The degree of Bcl-2 immunostaining, as well, was more intense in group 1 than in group 2 cases. In group 1 , the expression was found throughout the hyperplastic epithelium particularly in the basal cells (in positive normal cases, Bcl-2 was also expressed in the basal, but not in the secretory or luminal epithelium) while in group 2, Bcl-2 expression was observed in infiltrating lymphocytes as well as in malignant epithelial cells. Our results agreed those mentioned by Cardillo et al., ${ }^{(24)}$ and Shabaik et al., ${ }^{(31)}$ who stated that the hyperplastic epithelium as well as the normal prostatic basal epithelium became resistant to apoptosis induced by androgen withdrowal and expressed Bcl-2 after castration. These similarities between BPH and normal basal epithelial cells suggest that one explanation for the development of BPH may be an abnormal proliferation of basal cells. However, the trigger for such proliferation is not known. Furthermore, Berchem et al., ${ }^{(32)}$ and Raffo et al., ${ }^{(33)}$ showed that the $\mathrm{Bcl}-2$ expression is regulated by androgens: estrogens ratio in the $\mathrm{LNCaP}$ human prostate cancer cell line and found that the upregulation of Bcl-2 in vitro can protect the neoplastic prostatic cells from apoptosis. In addition, they suggested that an unexpected upregulation of Bcl-2 by androgen withdrowal protect $\mathrm{BPH}$ from apoptosis and reflects a dysregulation that characterizes this hyperplastic disorder.

The present study revealed that the Bcl-2 positivity was exclusively found in moderately to poorly differentiated (GS: 610) tumors. There was insignificant correlation between the Bcl-2 positivity and either Gleason score $(\mathrm{P}=0.125)$ or the histologic grade $(\mathrm{P}=0.146)$, however, a significant correlation was detected between the Bcl-2 immunoreactivity and $\mathrm{T}$ stage $(\mathrm{P}<0.05)$ since the Bcl-2 positivity was seen in $43.8 \%$ of $\mathrm{T}_{3}$ compared only to $12.1 \%$ of $\mathrm{T}_{1+2}$ tumors. Thus, our study considered Bcl-2 as a useful marker for discriminating locally advanced from organ confined prostatic cancer. The results coincided those described by Matsushima et al., (34) and Bubendolf et al., ${ }^{(35)}$ who, as well, stated that $\mathrm{Bcl}-2$ overexpression in surviving prostatic cancer cells after 
androgen ablation indicates a close relation to hormone resistance and suggested that the Bcl-2 positivity is a predictive of hormone response duration.

Combined analysis of ER- $\alpha$ and Bcl2 expression displayed the predominence of ER- $\alpha(+) / \mathrm{Bcl}-2(+)$ phenotype in group 1 and ER- $\alpha$ (-) / Bcl-2 (-) phenotype in group 2 . The later phenotype was absent in group 1 suggesting, as previously mentioned, that the prostatic growth and hyperplastic changes may be related to the exposure to increased intraprostatic estrogen levels. Furthermore, presence of both ER- $\alpha$ (+) / Bcl-2 (-) and ER- $\alpha$ (-) / Bcl-2 (+) phenotypes particularly in group 2 indicated that the ER- $\alpha$ and Bcl-2 molecules were independently expressed in prostatic carcinoma.

Although the relationship between Bcl-2 and ER positivities in prostatic carcinomas has not been previously fully examined, this study showed that combined ER- $\alpha \quad(+)$ and Bcl-2 (+) immunostaining detected the aggressive subgroup of prostatic cancer cases more accurately than either ER $\alpha(+)$ or $\mathrm{Bcl}-2(+)$ alone. Despite Bhargava et al., ${ }^{(36)}$ and Joensuu et al., ${ }^{(37)}$ established the association of ER positivity with Bcl-2 positivity in cancer breast explaining the estrogen dependency and favorable prognosis of this disorder, our study revealed that ER- $\alpha$ (-) / Bcl-2 (-) prostatic cancer cases had a significantly better prognosis than either ER $\alpha(+)$ or Bcl-2 $(+)$ cases $(\mathrm{P}<0.001)$. In addition, multivariate analysis, displayed that Bcl-2, but not ER- $\alpha$, proved to be an independent prognostic indicator $(\mathrm{P}<0.05)$. The findings of both combined and multivariate analysis in the present study were simulating those stated by Bonkhoff et al., ${ }^{(29)}$ and Matsushima et al., ${ }^{(35)}$ who also found that the $\mathrm{Bcl}-2$ positivity correlated with androgen independent prostatic cancer although it is still uncertain whether Bcl-2 expression inversely correlates with androgen receptor positivity. Moreover, Matsushima et al. ${ }^{(25)}$ reported that the poor prognosis of $\mathrm{Bcl}-2$ positive prostatic carcinomas is strongly supported by the experimental data of Raffo et al., ${ }^{(33)}$ study that the $\mathrm{LNCaP} / \mathrm{Bcl}-2$ transformed cells gave rise to tumors in castrated male mice. In conclusion, presence of ER- $\alpha$ in both normal prostatic stroma and epithelium accounts for a direct estrogen action on the two compartments and the increased epithelial than stromal ER- $\alpha$ immunostaining in $\mathrm{BPH}$ and $\mathrm{PC}$ suggests that involvement of these receptors in both lesions concerns mainly the epithelium. Furthermore, the application of $\mathrm{Bcl}-2$ and ER- $\alpha$ immunohistochemistry on prostatic biopsies is informative and may appear useful for a better understanding the biology and genesis of prostatic hyperplasia and carcinoma. Finally, Bcl-2 positivity was an independent prognostic indicator in prostatic carcinoma.

\section{Recommendation:}

Further future studies on Bcl-2 and ERs expression with combined and correlation analysis of both molecular positivities are needed, particularly in prostatic carcinomas, to establish the relationship between Bcl-2 expression and hormonal responsiveness in this group of patients.

\section{References:}

1. Krieg M., Nass R., Tunn S. (1993): Effect of aging on endogenous level of 5 alphadihydrotestosterone, estradiol and estrone in epithelium and stroma of normal and hyperplastic human prostate. J. Clin. Endocrinol. Metab.; 77: 375-81.

2. Coffy D.S and Walsh P.C. (1990): Clinical and experimental studies of prostatic hyperplasia. Urol. Clin. N. Am.; 17: 461-75.

3. Habenicht U.F. and El-Etreby M.F. (1991): Rationale for using aromatase inhibitors to manage benign prostatic hyperplasia. Experimental studies. J. Androl.; 12: 395-402.

4. Cox R.L. and Crowford D. (1995): Estrogens in the treatment of prostatic cancer. J. Urol.; 154: 1991-8.

5. Royuela M., Miguel M., Bethencourt F., Sanchez Chapado M., Fraile B. (2001): Estrogen receptors in normal, hyperplastic and carcinomatous human prostate. J. Endocrinol.; 168: 447-54. 
6. Hobisch A., Hittmair A., Daxebichler G., Wille S. (1997): Metastatic lesions from prostate cancer do not express estrogen and progesterone receptors. J. Pathol.; 182: 35661.

7. Byers M., Kuiper G., Gustafsson J., Park-Sarge O. (1997): Estrogen receptor $\beta$ mRNA expression in rat ovary. Molecular Endocrinol; 11: 172-82.

8. Green G., Glina P. Waterfield M., Baker A. (1996): Sequence and expression of human estrogen receptor complementary DNA. Science; 231: 1150-4.

9. Mosselman S., Polman J. and Dijkema R. (1996): ER-B: Identification and characterization of a novel human estrogen receptor. FEBS letters; 392: 49-53.

10. Kuiper G., Shughrue P., Merchen Thaler I. and Gustafsson J. (1998): The estrogen receptor $\beta$ subtype: A novel mediator of estrogen action in neuroendocrine systems. Frontiers in Neuroendocrinology; 19: 25386.

11. Bashirlahi N., Young J., Sidh S. and Sanefuji H. (1989): Androgen, estrogen and progesterone and their distribution in epithelial and stromal cells of human prostate. In Steroids Receptors, Metabolism and Prostate Cancer, PP. 240-56. Eds FH schroader \& HJ de Voogt. Amsterdam. Excerpta Medica.

12. Ehara H., Nass R. and Tunn S. (1995): Expression of estrogen receptor in diseased human prostate. Prostate; 27: 304-13.

13. Schulze H. and Claus S. (1990): Histological localization of estrogen receptors in normal and diseased human prostates by immunocytochemistry. Prostate; 16: 331-43.

14. Carruba G., Pfeffer U., Fecarotta E., Coviello D. (1994): Estradiol inhibits growth of hormone-non responsive PC3 human prostate cancer cells. Cancer Research; 54: 1190-3.

15. Castagnetta L. and Carruba G. (1995): Human prostate cancer. A direct role for estrogen. In Non-Reproductive Actions of Sex Steroids, Ciba Foundation Symposium; 191: 269-89.

16. Srinivasan G., Campbell E. and Bashirelahi N. (1995): Androgen, estrogen and progesterone receptors in normal and aging prostate. Microscopy Research and Technique; 30: 293-304.

17. Brolin J., Skoong L. and Ekman P. (1992): Immunohistochemistry and biochemistry in detection of androgen, progesterone and estrogen receptors in benign and malignant human prostatic tissue. Prostate; 20: 281-95.

18. Konishi N., Nakaoka S., Kitahori Y., Ohshima M. (1993): Immunohistochemical evaluation of estrogen receptor status in benign prostatic hypertrophy and in prostatic carcinoma. Oncology. 50: 259-63.

19. Tsujimoto Y., Gorham J., Cossam J. and Jaffe E. (1985): The $\mathrm{t} \quad(14 ; 18)$ chromosomal translocation involved in Bcell neoplasms. Science; 229: 1390-6.

20. Hockenbery D., Zutter M., Hickey W. and Nahm M. (1991): Bcl-2 protein is topographically restricted in tissues characterized by apoptotic cell death. Proc. Natl. Acad. Sci. USA; 88: 6961-5.

21. Hockenbery D., Nunez G., Milliman C. and Schreiber R. (1998): Bcl-2 is an inner mitochondrial membrane protein that blocks programmed cell death. Nature; 348 : 334-6.

22. Kyprianou N. and Isaacs. J.T. (1998): Activation of programmed cell death in the rat ventral prostate after castration. J. Endocrinol., 122: 552-8.

23. McDonnell T., Troncoso P., Brisbay S. and Logothetis C. (1992): Expression of protooncogene Bcl-2 in the prostate. Cancer Research; 52: 6940-4.

24. Cardillo M., Berchem G., Tarkington A., Krajewski S. (1997): Resistance to apoptosis and upregulation of bcl-2 in prostatic hyperplasia after androgen deprivation. J. Urol.; 158: 212-6.

25. Colombel. M., Symmans F., Gil S. and O'Toole K. (1993): Detection of apoptosissuppressing protein $\mathrm{Bcl}-2$ in hormone refractory Prostate cancers. Am. J. Pathol.; 143 (8): 390-400.

26. Schweikert H., Tunn U., Habenicht U. and Arnold. J. (1993): Effects of estrogen deprivation on human benign prostatic hyperplasia. J. Ster. Biochem and Molec. Biol., 44: 573-6.

27. Mobbs B., Johson I. and Liu Y. (1990): Quantitation of cytosolic and nuclear estrogen and progesterone receptor in benign, untreated and treated malignant prostate. Prostate; 16: 235-44.

28. Pennie W., Aldridge T. and Brooks A. (1998): Differential activation by xenoestrogens of ER- $\alpha$ and ER- $\beta$ J. Endocrinol; 158: 11-14.

29. Bonkhoff H., Fixemer T. and Hunsicker I. (1999): Estrogen receptor expression in prostate cancer and premalignant lesions. Am. J. Pathol.; 155: 641-7. 
30. Kirschenbaum A., Ren M., Erenburg I. and Schater B. (1994): Estrogen receptor mRNA expression in human benign prostatic hyperplasia. J. Androl.; 15: 52833.

31. Shabaik A., Krajewski S., Burgan A., Krajewski M. and Reed J. (1995): Bcl-2 protooncogene expression in normal, hyperplastic and neoplastic prostatic tissue. J. Urol. Pathol; 3: 17-22.

32. Berchem G. Bosseler M., Sugars L. and Voeller H. (1995): Androgens induce resistance to bcl-2 mediated apoptosis in LNCa P-prostate cancer cells. Cancer Res.; 55: 735-41.

33. Raffo A., Perlman H., Chen M., Day M. and Buttyan R. (1995): Overexpression of Bcl-2 protects prostate cancer cells from apoptosis. Cancer Res.; 55: 4438-42.
34. Matsushima H., Kitamura T., Goto T. and Hosaka Y. (2002): Combined analysis with Bcl-2 and ERs immunostaining in prostatic carcinoma. Prostate Cancer and Prostatic Diseases; 5: 105-10.

35. Bubendorf L., Sauter G., Moch H. and Jordan P. (2003): Prognostic significance of $\mathrm{Bcl}-2$ in clinically localized prostate cancer. Prostate; 27: 304-13.

36. Bhargava V., Kell D., Van de Rijn M. and Warnke R. (1994): $\mathrm{Bcl}-2$ immunoreactivity in breast carcinoma correlates with hormone receptor positivity. Am. J. Pathol.; 145: 535-40.

37. Joensuu H., Pylkkaen L., and Toikkanen S. (1994): Bcl-2 protein expression and long-term survival in breast cancer. Am. J. Pathol; 145: 1191-6. 


\section{دراسة هستوكيميائية مناعية لإظهار بروتين بى-سى-ال-2 ومستقبلات

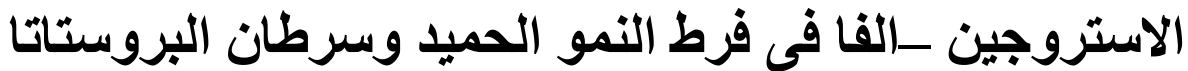

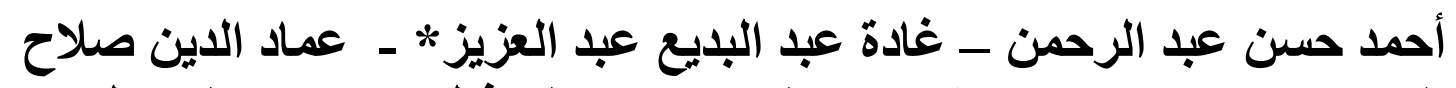

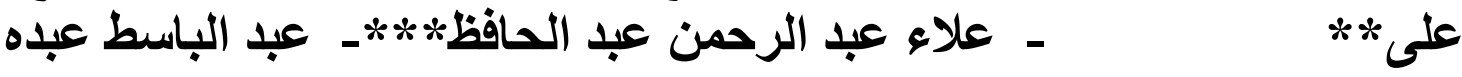

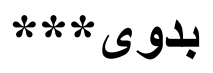

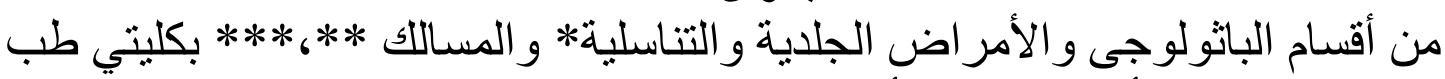

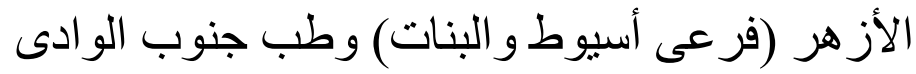

تعتبر البروستاتا من الأنسجة التى تتعرض بشكل و اضـح لأمر اض فرط النمو والأور ام

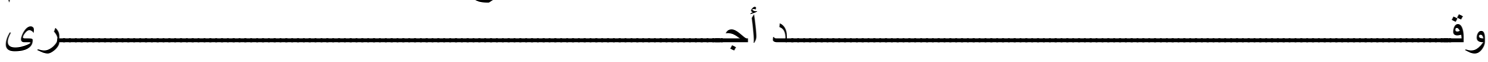
هذا البحث على 120 حالة قسمت كمجمو عتين: الأولى: وتشتمل 40 حالة مـن فرط النمو الحميد

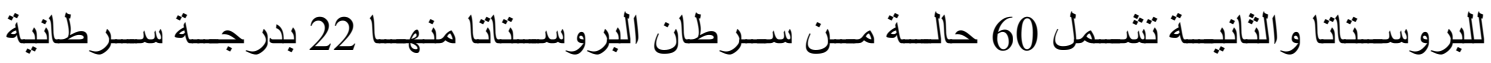
منخفضة(مقياس جليسون من 2-6) ، 38 بدرجة سرطانية عالية (مقياس جليسون من الئس

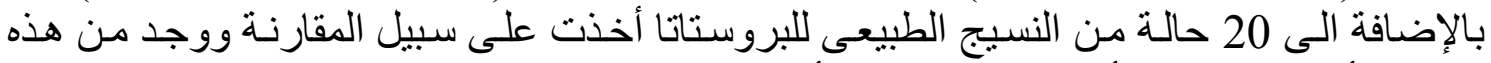

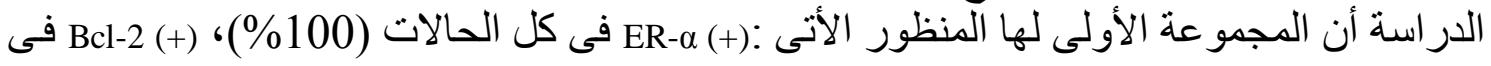

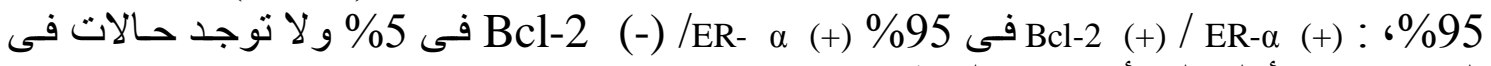

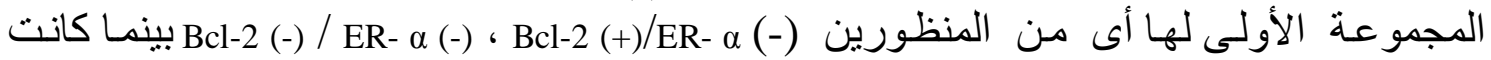

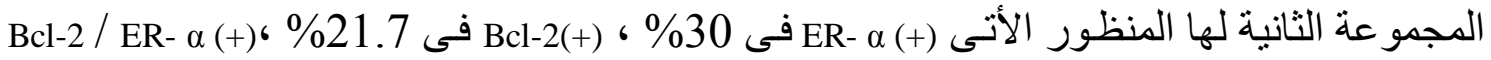

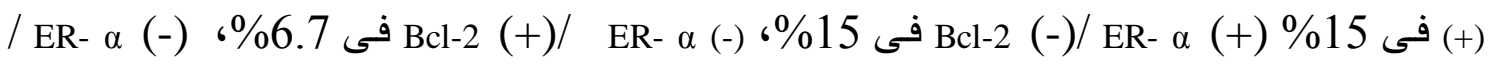

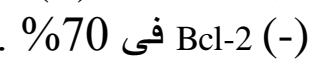

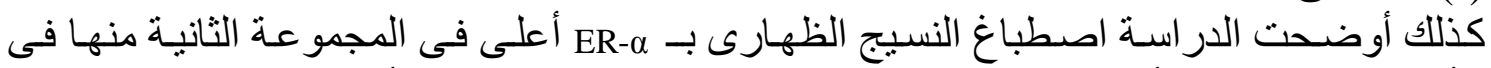

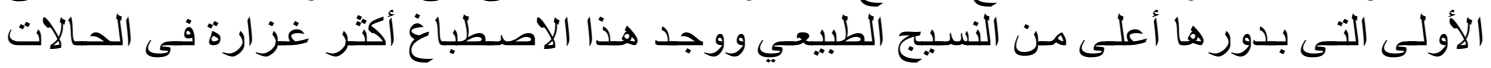

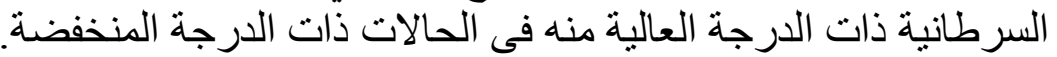

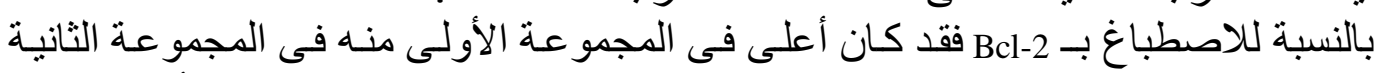

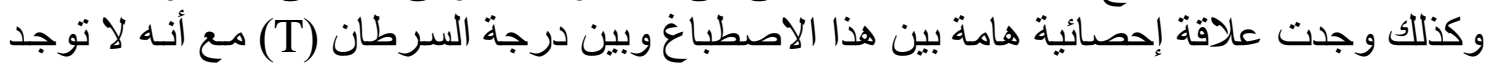

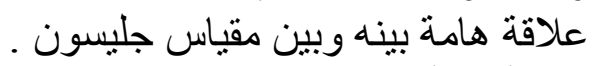

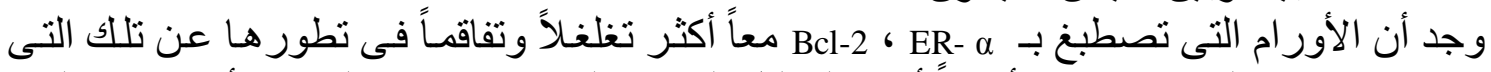

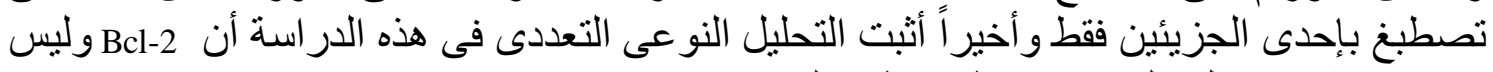
مؤشر مستقل بالتكهن بنشاط سرطان البروستاتا . ERونستنتج من هذه الدر استة:

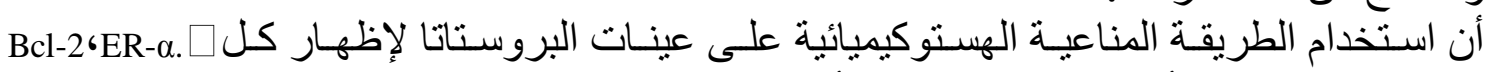

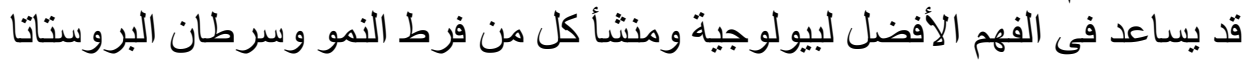

